\title{
Inhibition of PDGFR phosphorylation and Src and Akt activity by GN963 leads to therapy of human pancreatic cancer growing orthotopically in nude mice
}

\author{
CHERYL H. BAKER ${ }^{1}$, JOSE G. TREVINO ${ }^{2}$, JUSTIN M. SUMMY ${ }^{2}$, FAHAO ZHANG $^{2}$, \\ ALEXIS CARON $^{3}$, MARK NESBIT ${ }^{3}$, GARY E. GALLICK ${ }^{2}$ and ISAIAH J. FIDLER ${ }^{2}$ \\ ${ }^{1}$ Cancer Research Institute of M.D. Anderson Cancer Center Orlando, Orlando, FL; ${ }^{2}$ Department of Cancer Biology, \\ The University of Texas M.D. Anderson Cancer Center, Houston, TX, USA; ${ }^{3}$ Centelion SAS, Paris, France
}

Received February 13, 2006; Accepted March 7, 2006

\begin{abstract}
GN963 is a tyrosine kinase inhibitor with activity against platelet-derived growth factor receptor (PDGFR) and Src kinases. We determined whether oral administration of GN963, alone or in combination with gemcitabine produces therapy against L3.6pl human pancreatic cancer cells growing orthotopically in nude mice. The optimal biological dosage of oral GN963 was determined to be $100 \mathrm{mg} / \mathrm{kg}$ every $48 \mathrm{~h}$. Seven days after injection of L3.6pl cells into the pancreas of nude mice, mice $(\mathrm{n}=10)$ were treated with vehicle (control), thrice-weekly oral GN963 (100 mg/kg), twice-weekly intraperitoneal gemcitabine $(100 \mathrm{mg} / \mathrm{kg})$, or GN963 plus gemcitabine. Treatment with gemcitabine did not significantly differ from control. In contrast, treatment with GN963 (100 mg/ $\mathrm{kg}$ ) or GN963 plus gemcitabine produced a $52 \%$ and $81 \%$ decrease in tumor volume, respectively. GN963 plus gemcitabine completely inhibited the incidence of liver metastasis. Administration of GN963 inhibited PDGFR phosphorylation in both tumor and tumor-associated endothelial cells, decreased Src and Akt kinase activity in tumor cells, decreased microvessel density, and decreased tumor cell proliferation, while increasing apoptosis of tumor and tumor-associated endothelial cells. Collectively, these data indicate that targeting PDGFR, Src, and Akt on tumor and tumor-associated endothelial cells may be an effective therapy for human pancreatic carcinoma.
\end{abstract}

\section{Introduction}

Pancreatic ductal adenocarcinoma is the fourth most common cause of cancer-related death in the United States (1). At the

Correspondence to: Dr Cheryl H. Baker, Cancer Research Institute of M. D. Anderson Cancer Center Orlando, 110 Bonnie Loch Court, Orlando, FL 32806, USA

E-mail: cheryl.baker@orhs.org

Key words: pancreatic cancer, platelet-derived growth factor receptor, Src, endothelial cells time of diagnosis, $90 \%$ of patients have surgically unresectable disease owing to aggressive invasion and metastasis. Current chemotherapy regimens with the most effective agents, such as gemcitabine, prolong life only by 6 months or less $(2,3)$. Thus, a major goal of research has been the identification of a more effective therapy for pancreatic cancer.

Recent advances in understanding the biology of pancreatic cancer may offer new therapeutic approaches. One such approach is to alter the pathological signaling pathways of cancer cells, specifically those that interact with vascular endothelial cells in the tumor microenvironment. Human pancreatic cancers express high levels of the epidermal growth factor receptor (EGFR) (4-9), vascular endothelial growth factor receptor (VEGFR) (9-11), and platelet-derived growth factor receptor (PDGFR) (9,12-14); and overexpression of these receptors is associated with rapidly progressive disease. Recent data indicate that the well-recognized biological heterogeneity of neoplasms includes the expression of tyrosine kinase receptors (15), and preclinical studies combining chemotherapy with tyrosine kinase inhibitors targeting EGFR, VEGFR, and/or PDGFR have shown potent efficacy against human pancreatic tumors growing in the pancreas of nude mice $(9,1,2,16-21)$.

The progression of pancreatic cancer has been associated with deregulation of several signaling molecules, and inhibition of the activity of intracellular signal transducers has been shown to block proliferation, migration, invasion, and metastasis of multiple cancers, including pancreatic cancer $(22,23)$. One group of these signal transducers, the Src family of protein tyrosine kinases, is a potential therapeutic target that has received considerable attention. The Src family comprises a number of nonreceptor intracellular tyrosine kinases that mediate a variety of cellular pathways $(24,25)$. Src kinases are overexpressed in a variety of human tumors, including cancers of the colon $(26,27)$, breast $(28,29)$, and pancreas (30), and they are an integral part of tumor cell signaling pathways associated with migration, proliferation, adhesion, and angiogenesis (31). Receptor tyrosine kinases that signal through Src kinases include PDGFRs, EGFRs, and fibroblast growth factor receptors $(25,32)$. For example, PDGF-induced c-Src kinase activation by PDGFR tyrosine kinase phosphorylation and c-Src binding to PDGFR constitutes an early process 
necessary for receptor signaling activation in different cell types (33-39). The Src family kinases also regulate the phosphatidylinositol 3'kinase (PI3K/)Akt, and the MAPK(Erk) kinase (MEK/mitogen-activated protein kinase (extracellular signal-regulated kinase) (40). Hence, inhibition of Src results in inhibition of the Src-dependent matrix metalloproteinases MMP-2 and MMP-9, inhibition of constitutive and EGFactivated VEGF production, inhibition of interleukin-8 expression, and decreased invasiveness of pancreatic cancer cells (41-45). Src inhibition with a newly identified Src family tyrosine kinase inhibitor, AZM475271, was recently shown to produce significant antitumor and antimetastatic activity in an orthotopic model of pancreatic cancer in nude mice (46).

Strategies to inhibit PDGFR phosphorylation and Src kinase activity, either alone or in combination with standard chemotherapy, should be effective against the growth and metastasis of human pancreatic cancer. However, while recent reports have shown the effect of targeted therapy directed at inhibiting PDGFR $(8,12)$ or Src activity $(43-46)$ in pancreatic cancer, the therapeutic effect of inhibiting both PDGFR and Src in combination with chemotherapy is unknown. GN963 [trans-4-(6,7-dimethoxyquinoxalin-2-ylamino)cyclohexanol sulfate (47); Centelion, Paris, France], a tyrosine kinase inhibitor of the pyrrolo-pyrimidine class, has been shown to inhibit the intracellular domain of the PDGFR kinases with a $50 \%$ inhibitory concentration of $0.7 \mathrm{nM}$. GN963 also inhibits other tyrosine kinases, though less effectively; for example, it inhibits c-Src with a $50 \%$ inhibitory concentration of $3.0 \mathrm{nM}$. The present study reports the therapeutic efficacy of GN963 against the growth and metastasis of human pancreatic cancer cells implanted into the pancreas of nude mice.

\section{Materials and methods}

Pancreatic cancer cell lines and culture conditions. The human metastatic pancreatic cancer cell line, L3.6pl (48), was maintained in Dulbecco's modified Eagle's medium supplemented with $5 \%$ fetal bovine serum, sodium pyruvate, nonessential amino acids, L-glutamine, a two-fold vitamin solution (Life Technologies, Grand Island, NY), and a penicillin-streptomycin mixture (Flow Laboratories, Rockville, $\mathrm{MD})$. Adherent monolayer cultures were maintained on plastic and incubated at $37^{\circ} \mathrm{C}$ in a mixture of $5 \% \mathrm{CO}_{2}$ and $95 \%$ air. The cultures were free of Mycoplasma and the following pathogenic murine viruses: reovirus type 3, pneumonia virus, $\mathrm{K}$ virus, Theiler's encephalitis virus, Sendai virus, minute virus, mouse adenovirus, mouse hepatitis virus, lymphocytic choriomeningitis virus, ectromelia virus, and lactate dehydrogenase virus (assayed by MA BioProducts, Walkersville, MD). The cultures were maintained for no longer than 12 weeks after being recovered from frozen stocks.

Reagents. GN963 was stored at room temperature in $0.5 \%$ $\mathrm{w} / \mathrm{v}$ methylcellulose and $0.2 \%$ Tween-80 in sterile water (47). Gemcitabine (Gemzar, Eli Lilly, Indianapolis, IN) was kept at room temperature and dissolved in $0.9 \% \mathrm{NaCl}$ on the day of use (2). All of the reagents used in tissue culture were free of endotoxin, as determined by the Limulus amebocyte lysate assay (sensitivity limit of $0.125 \mathrm{ng} / \mathrm{ml}$ ) purchased from Associates of Cape Cod (Falmouth, MA). We used the following antibodies: polyclonal rabbit anti-PDGFBB, polyclonal rabbit anti-PDGFR- $\beta$ and polyclonal rabbit antiphosphorylated PDGFR- $\beta$ (PDGFR- $\beta-P$ ) (Santa Cruz Biotechnology, Santa Cruz, CA); rat anti-mouse CD31/ PECAM (platelet/endothelial cell adhesion molecule)-1 (PharMingen International, San Diego, CA); mouse antiproliferative cellular nuclear antigen (PCNA) clone PC-10 (Dako A/S, Copenhagen, Denmark); polyclonal rabbit antiphosphorylated $\mathrm{Src}^{\mathrm{Y} 418}$ (P-Src), rabbit anti-Akt and rabbit anti-phosphorylated $\mathrm{Akt}^{\mathrm{S} 473}$ (P-Akt) (Cell Signaling, Beverly, MA); monoclonal mouse anti-human c-Src (mAb 327; Calbiochem, La Jolla, CA); AffiniPure goat anti-mouse IgG $\mathrm{F}(\mathrm{ab})_{2}$, Texas Red-conjugated goat anti-rat IgG, peroxidaseconjugated goat anti-rat IgG, and peroxidase-conjugated goat anti-rabbit IgG (Jackson Research Laboratories, West Grove, $\mathrm{CA}$ ); peroxidase-conjugated rat anti-mouse IgG2a (Serotec; Harlan Bioproducts for Science, Indianapolis, IN); and Alexa Fluor 488-conjugated goat anti-rabbit IgG. Other reagents used for IHC analysis included Hoechst Dye 3342 (molecular weight $615.9 \mathrm{~g} / \mathrm{mole}$; Hoechst, Warrington, PA), stable 3,3'diaminobenzidine (Research Genetics, Huntsville, AL), Gill's hematoxylin (Sigma Chemical, St. Louis, MO), and pepsin (Biomeda, Foster City, CA). The terminal deoxynucleotidyl transferase-mediated dUTP-biotin end-labeling (TUNEL) assay was performed using a commercial apoptosis detection kit (Promega, Madison, WI) with modifications.

Cell proliferation. Tumor cells $(1 \times 103)$ were seeded into $39-\mathrm{mm}^{2}$ wells of flat-bottomed 96-well plates in triplicate and allowed to adhere overnight. The cultures were then washed and refed with medium (negative control) or medium containing increasing concentrations of GN963. After 3 days (control cultures did not reach confluence), the number of metabolically active cells was determined by MTT assay (49). After 2-4 h of incubation in medium containing $0.42 \mathrm{mg} / \mathrm{ml}$ of MTT, cells were lysed in DMSO. The conversion of MTT to formazan by metabolically viable cells was monitored by an MR-5000 96-well microtiter plate reader at $570 \mathrm{~nm}$ (Dynatech, Inc, Chantilly, VA). Growth inhibition was calculated using the following formula: cytostasis $(\%)=[1-(\mathrm{AB})] \times 100$, where $\mathrm{A}$ is the absorbance of treated cells and $\mathrm{B}$ is the absorbance of control cells.

Animals and orthotopic implantation of tumor cells. Male athymic nude (NCI- $n u$ ) mice were purchased from the Animal Production Area of the National Cancer Institute's Frederick Cancer Research and Development Center (Frederick, MD). The mice were housed and maintained under specific pathogenfree conditions in facilities approved by the American Association for Accreditation of Laboratory Animal Care and in accordance with current regulations and standards of the U.S. Department of Agriculture, Department of Health and Human Services, and National Institutes of Health. The mice were used in accordance with institutional guidelines when they were 8-12 weeks old.

For production of tumors, L3.6pl cells were harvested from subconfluent cultures by brief exposure to $0.25 \%$ trypsin and $0.02 \%$ EDTA. Trypsinization was stopped with medium containing $10 \%$ fetal bovine serum, and the cells were washed once in serum-free medium and resuspended in HBSS. 
Suspensions consisting of single cells with $>90 \%$ viability were injected into the pancreas of each mouse as described previously (48). The mice were sacrificed when moribund (5 weeks after injection) and subjected to necropsy, as described below.

Pharmacodynamic endpoint of target inhibition. Seven days after implantation of L3.6pl human pancreatic cancer cells into the pancreas, mice were randomized to receive one of four treatments ( $\mathrm{n}=50$ mice per group): daily oral administration of vehicle solution alone $(0.5 \% \mathrm{w} / \mathrm{v}$ methylcellulose and $0.2 \%$ Tween- 80 in sterile water; control group) or daily oral administration of 50,100 , or $250 \mathrm{mg} / \mathrm{kg}$ GN963. Mice from each group were treated for 2 consecutive days, at which time treatment was stopped and, 15 min later, five mice were bled and sacrificed. The remaining mice in each group were sacrificed (five mice at a time) $30 \mathrm{~min}$ or 1, 2, 4, 8, 12, 24, 48 , or $72 \mathrm{~h}$ after cessation of treatment. All tumors were processed for IHC as described below.

Treatment of established orthotopic human pancreatic carcinomas. Seven days after implantation of tumor cells into the pancreas of each mouse, five mice were sacrificed to confirm the presence of tumor lesions. Tumor volumes were calculated using the following formula: $0.5 \mathrm{x}$ length $\mathrm{x}$ (width) ${ }^{2}$. At that time, the median tumor volume was $21 \mathrm{~mm}^{3}$. Histological examination confirmed the lesions to be actively growing pancreatic carcinomas.

To determine the optimal biological dose of GN963 given orally to inhibit phosphorylation of PDGFR- $\beta$ on tumor cells and tumor-associated endothelial cells, mice were randomized to receive one of eight treatments ( $n=10$ mice per group): i) thrice-weekly oral administration of vehicle solution alone (control group), ii) thrice-weekly oral administration of $50 \mathrm{mg} /$ $\mathrm{kg}$ GN963, iii) thrice-weekly oral administration of $100 \mathrm{mg} / \mathrm{kg}$ GN963, iv) thrice-weekly oral administration of $250 \mathrm{mg} / \mathrm{kg}$ GN963, v) twice-weekly intraperitoneal (i.p.) injection of $125 \mathrm{mg} / \mathrm{kg}$ gemcitabine alone, vi) thrice-weekly oral administration of $50 \mathrm{mg} / \mathrm{kg}$ GN963 and twice-weekly i.p. injection of $125 \mathrm{mg} / \mathrm{kg}$ gemcitabine, vii) thrice-weekly oral administration of $100 \mathrm{mg} / \mathrm{kg}$ GN963 and twice-weekly i.p. injection of $125 \mathrm{mg} / \mathrm{kg}$ gemcitabine, or viii) thrice-weekly oral administration of $250 \mathrm{mg} / \mathrm{kg}$ GN963 and twice-weekly i.p. injection of $125 \mathrm{mg} / \mathrm{kg}$ gemcitabine. Treatments were continued for 4 weeks. The mice were sacrificed on day 35 and subjected to necropsy. The volumes of the pancreatic tumors and the incidence of liver metastases were recorded.

In a second experiment, the most effective dose of GN963 $(100 \mathrm{mg} / \mathrm{kg})$ was used. Groups of mice $(\mathrm{n}=10)$ were treated as follows: thrice-weekly oral administration of vehicle solution alone (control group), thrice-weekly oral administration of $100 \mathrm{mg} / \mathrm{kg}$ GN963, twice-weekly i.p. injection of $100 \mathrm{mg} / \mathrm{kg}$ gemcitabine, and a combination of GN963 and gemcitabine. The mice were treated for 4 weeks and then sacrificed and subjected to necropsy as described below.

Necropsy procedures and histological studies. Mice were sacrificed, and their body weights were recorded. Primary tumors in the pancreas were excised, measured, and weighed. For IHC and hematoxylin and eosin (H\&E) staining procedures, part of the primary tumor tissue was fixed in formalin and embedded in paraffin. Another part of the tumor was embedded in OCT compound (Miles, Elkhart, IN), snapfrozen in liquid nitrogen, and stored at $-70^{\circ} \mathrm{C}$. Visible liver metastases were counted and recorded with the aid of a dissecting microscope, and the tissues were processed for H\&E staining.

Immunohistochemical analysis. Frozen tissues used for identification of CD31/PECAM-1 and phosphorylated Src (P-Src; green fluorescence) were sectioned (8-10 $\mu \mathrm{m})$, mounted on positively charged Plus slides (Fisher Scientific, UK), and air-dried for $30 \mathrm{~min}$. The sections were fixed in cold acetone for $5 \mathrm{~min}$, followed by 1:1 acetone:chloroform (vol:vol) for $5 \mathrm{~min}$, and then acetone for $5 \mathrm{~min}$. The sections were then washed with PBS and immunohistochemical staining for CD31 was performed as previously described (50). A CD31positive reaction was visualized by incubating the slides in stable 3,3'-diaminobenzidine (DAB) for 10-20 min. The sections were rinsed with distilled water, counterstained with Gill's hematoxylin for $1 \mathrm{~min}$, and mounted with Universal Mount (Research Genetics, Huntsville, AL). Control samples were exposed to secondary antibody alone and demonstrated no specific staining.

Sections analyzed for P-Src were incubated with rabbit anti-P-Src (1:50 dilution in PBS) for $18 \mathrm{~h}$ at $4^{\circ} \mathrm{C}$. The samples were then rinsed three times for $3 \mathrm{~min}$ each with PBS and incubated at room temperature for $1 \mathrm{~h}$ with a 1:200 dilution of secondary Alexa Fluor 488 conjugated goat anti-rabbit avoiding exposure to light. All samples were washed twice with PBS containing $0.1 \%$ Brij and washed with PBS for $5 \mathrm{~min}$, and nuclear staining was performed by incubating the samples with $300 \mathrm{mg} / \mathrm{ml} \mathrm{Hoechst} \mathrm{dye} \mathrm{diluted} \mathrm{in} \mathrm{PBS} \mathrm{for} 2 \mathrm{~min}$. The nuclei were identified by blue staining and P-Src was identified by green fluorescence. Control samples were exposed to secondary antibody alone and demonstrated no specific staining.

Paraffin-embedded tissues were used for identification of PCNA, PDGF BB, PDGFR- $\beta$, PDGFR- $\beta-P$, Src, and activated Akt (P-Akt). Sections (4-6 $\mu \mathrm{m}$ thick) were mounted on positively-charged Superfrost slides (Fischer Scientific, Co., Houston, TX) and dried overnight. Sections were deparaffinized in xylene and then treated with a graded series of alcohol $\left[100,95\right.$, and $80 \%$ ethanol (v/v) in double distilled $\left.\mathrm{H}_{2} 0\right]$ and rehydrated in PBS (pH 7.5) Sections were treated with $10 \mathrm{mM}$ citrate buffer, $\mathrm{pH} 6.0$ and microwaved for $10 \mathrm{~min}$ for antigen retrieval. Sections were blocked with $3 \% \mathrm{H}_{2} \mathrm{O}_{2}$ in PBS for $12 \mathrm{~min}$ and washed with PBS $(3 \times 5 \mathrm{~min})$. Sections analyzed for PCNA, PDGF BB, and PDGFR- $\beta$ were incubated with protein blocking solution containing 5\% normal horse serum and $1 \%$ normal goat serum for $20 \mathrm{~min}$. Sections analyzed for PDGFR-ß-P, Src and P-Akt were blocked with $4 \%$ fish gel for $20 \mathrm{~min}$. Samples were then incubated with the appropriate primary antibody; anti-PCNA (1:100), anti-PDGF BB (1:100 dilution), anti-PDGFR- $\beta$ and anti-PDGFR- $-\mathrm{P}$ (1:200 dilution), anti-Src (1:50 dilution), and anti-phospho-Akt (1:100 dilution), overnight at $4^{\circ} \mathrm{C}$. IHC for Src was carried out using AvidinBiotin blocking (Biocare Medical, Concord, MA), followed by goat anti-rabbit biotinylation (Biocare Medical) and streptavadin-HRP incubation for $30 \mathrm{~min}$ each at room temp- 
erature. IHC for phospho-Akt was carried out using goatanti-rabbit biotinylation and streptavadin-HRP (Dako, Denmark) incubation for $30 \mathrm{~min}$ each at room temperature. A positive reaction was visualized by incubating the slides in stable 3,3'-diaminobenzidine (DAB) for 10-20 min. The sections were rinsed with distilled water, counterstained with Gill's hematoxylin for $1 \mathrm{~min}$, and mounted with Universal Mount (Research Genetics, Huntsville, AL). Control samples were exposed to secondary antibody alone and demonstrated no specific staining.

For double-staining procedures, the samples were incubated with rat monoclonal anti-mouse CD31 antibody (human crossreactive; $1: 400$ ) for $18 \mathrm{~h}$ at $4^{\circ} \mathrm{C}$. After the samples were rinsed for $4 \times 3$ min with PBS, they were incubated with Texas Redconjugated secondary goat anti-rat antibody (1:200) for $1 \mathrm{~h}$ at room temperature in the dark. Immunostaining for PDGFR- $\beta-P$ was performed after CD31 staining. Samples were incubated with protein-blocking solution for $5 \mathrm{~min}$ at room temperature and incubated with a 1:200 dilution of anti-PDGFR- $\beta-P$ antibody for $18 \mathrm{~h}$ at $4^{\circ} \mathrm{C}$. The samples were then rinsed four times with PBS for 3 min each, and the slides were incubated with a 1:200 dilution of Alexa Fluor 488-conjugated goat anti-rabbit IgG for $1 \mathrm{~h}$ at room temperature in the dark. All samples were washed twice with PBS containing $0.1 \%$ Brij and then washed with PBS alone for 5 min. Nuclear staining was performed by incubating the samples with $300 \mu \mathrm{g} / \mathrm{ml}$ Hoechst dye diluted in PBS for 2 min. Endothelial cells were identified by red fluorescence, and activated PDGFR- $\beta$ was identified by green fluorescence. Colocalization (yellow) of red-stained endothelial cells with green-stained PDGFR- $\beta-P$ was obtained by superimposing two images.

TUNEL was performed using a commercially available apoptosis detection kit (Promega, Madison, WI) with the following modifications. Samples were fixed with $4 \%$ paraformaldehyde (methanol-free) for $10 \mathrm{~min}$ at room temperature, washed twice with PBS for $5 \mathrm{~min}$, and incubated with $0.2 \%$ Triton X-100 for $15 \mathrm{~min}$ at room temperature. After being washed for $2 \times 5$ min with PBS, the samples were incubated with equilibration buffer (from the kit) for $10 \mathrm{~min}$ at room temperature. The equilibration buffer was drained, and reaction buffer containing equilibration buffer, nucleotide mix, and TdT enzyme was added to tissue sections, which were incubated in a humidified chamber at $37^{\circ} \mathrm{C}$ for $1 \mathrm{~h}$, avoiding exposure to light. Immersing the samples in $2 \mathrm{X}$ SSC for 15 min terminated the reaction, and samples were washed for $3 \times 5$ min to remove unincorporated fluorescein-dUTP. Fluorescent bleaching was minimized by treating slides with an enhancing reagent (ProLong solution).

Immunostained sections were examined using a x40 objective (Zeiss Plan-Neofluar) on an epifluorescence microscope equipped with narrow bandpass excitation filters mounted in a filter wheel (Ludl Electronic Products, Hawthorne, NY) to individually select for green and red fluorescence. Images were captured using a cooled chargecoupled device camera (Photometrics, Tucson, AZ) and SmartCapture software (Digital Scientific, Cambridge, UK) on a Macintosh computer. Images were further processed using Adobe Photoshop software (Adobe Systems, Mountain View, CA). Endothelial cells were identified by red fluorescence, and DNA fragmentation was detected by localized green and yellow fluorescence within the nuclei of apoptotic cells. Quantification of apoptotic endothelial cells was expressed as an average of the ratio of apoptotic endothelial cells to the total number of endothelial cells in 5-10 random $0.011-\mathrm{mm}^{2}$ fields at $\mathrm{x} 400$ magnification.

Quantification of microvessel density, PCNA and absorbance. Microvessels were quantified according to a previously described method $(50,51)$ in 10 random $0.159-\mathrm{mm}^{2}$ fields at x100 magnification. The number of PCNA-positive cells was quantified in 10 random $0.159-\mathrm{mm}^{2}$ fields at $\mathrm{x} 100$ magnification. The absorbance of 100 PDGFR-b and activated PDGFRb-positive cells in 10 random $0.039-\mathrm{mm}^{2}$ fields at x100 magnification of tumor tissues was measured using Optimas image analysis software (48). The samples were not counterstained, so the absorbance was due solely to the product of the immunohistochemical reaction.

Statistical analysis. Pancreatic tumor volumes, numbers of PCNA- and CD31-positive cells, and percentages of apoptotic endothelial cells were compared by unpaired Student's t-test. The incidence of liver metastasis between the groups was compared using Fisher's exact test.

Western blot analysis of Src and Akt phosphorylation after treatment with GN963. Serum-starved L3.6pl cells were treated with GN963 (0-350 $\mu \mathrm{M})$ for $1 \mathrm{~h}$ and then incubated with or without $10 \mathrm{ng} / \mathrm{ml}$ recombinant human PDGF BB for $15 \mathrm{~min}$, washed, scraped into phosphate-buffered saline (PBS) containing $5 \mathrm{mM}$ EDTA and $1 \mathrm{mM}$ sodium orthovanadate, and centrifuged. The pellet was resuspended in lysis buffer [20 mM Tris- $\mathrm{HCl}$ (pH 8.0), $137 \mathrm{mM} \mathrm{NaCl}, 10 \%$ glycerol, $2 \mathrm{mM}$ EDTA, $1 \mathrm{mM}$ phenylmethylsulfonyl fluoride, $20 \mu \mathrm{M}$ leupeptin, and $0.15 \mathrm{unit} / \mathrm{ml}$ aprotinin], sonicated, and centrifuged to recover insoluble protein. Protein lysates were separated by SDS-PAGE on $7.5 \%$ polyacrylamide gels and transferred onto $0.45-\mu \mathrm{m}$ nitrocellulose membranes. The membranes were blocked with $3 \%$ bovine serum albumin in Tris-buffered saline [20 mM Tris- $\mathrm{HCl}(\mathrm{pH} 7.5)$ and $150 \mathrm{mM}$ $\mathrm{NaCl}$, probed with polyclonal rabbit anti-PDGFR- $\beta$ (1:500), polyclonal rabbit anti-phosphorylated PDGFR- $\beta$ (1:200), monoclonal mouse anti-human c-Src antibody (1:1000), polyclonal rabbit anti-P-Src antibody $(1: 1000)$ in TTBS, rabbit anti-Akt (1:1000), or rabbit anti-P-Akt antibody (1:1000). The membranes were then incubated with sheep anti-mouse $\operatorname{IgG}$ (1:2000) or horseradish peroxidase-conjugated donkey antirabbit IgG (1:2000) in TTBS. Protein bands were visualized using the ECL detection system.

Immunoprecipitation and immune complex kinase assay. Cleared cell lysates (500 $\mu \mathrm{g}$ protein) were incubated overnight at $4^{\circ} \mathrm{C}$ with $10 \mu \mathrm{l}$ of monoclonal anti-c-Src antibody. Immune complex kinase assays were performed as previously described (52). Briefly, immune complexes were formed by the addition of $10 \mu \mathrm{l}$ of rabbit anti-mouse IgG for $2 \mathrm{~h}$, followed by $50 \mu \mathrm{l}$ of $10 \%$ (v/v) formalin-fixed Pansorbin (Staphylococcus aureus, Cowan strain; Calbiochem) for $60 \mathrm{~min}$. Pellets were then washed three times in a buffer consisting of $0.1 \%$ Triton $\mathrm{X}-100,150 \mathrm{mM} \mathrm{NaCl}$, and $10 \mathrm{mM}$ sodium phosphate. Reactions were initiated at $22^{\circ} \mathrm{C}$ by adding $10 \mu \mathrm{Ci}$ of $\left[\gamma^{\sim 32} \mathrm{P}\right]-$ 


\section{PDGFR- $\beta-P$}
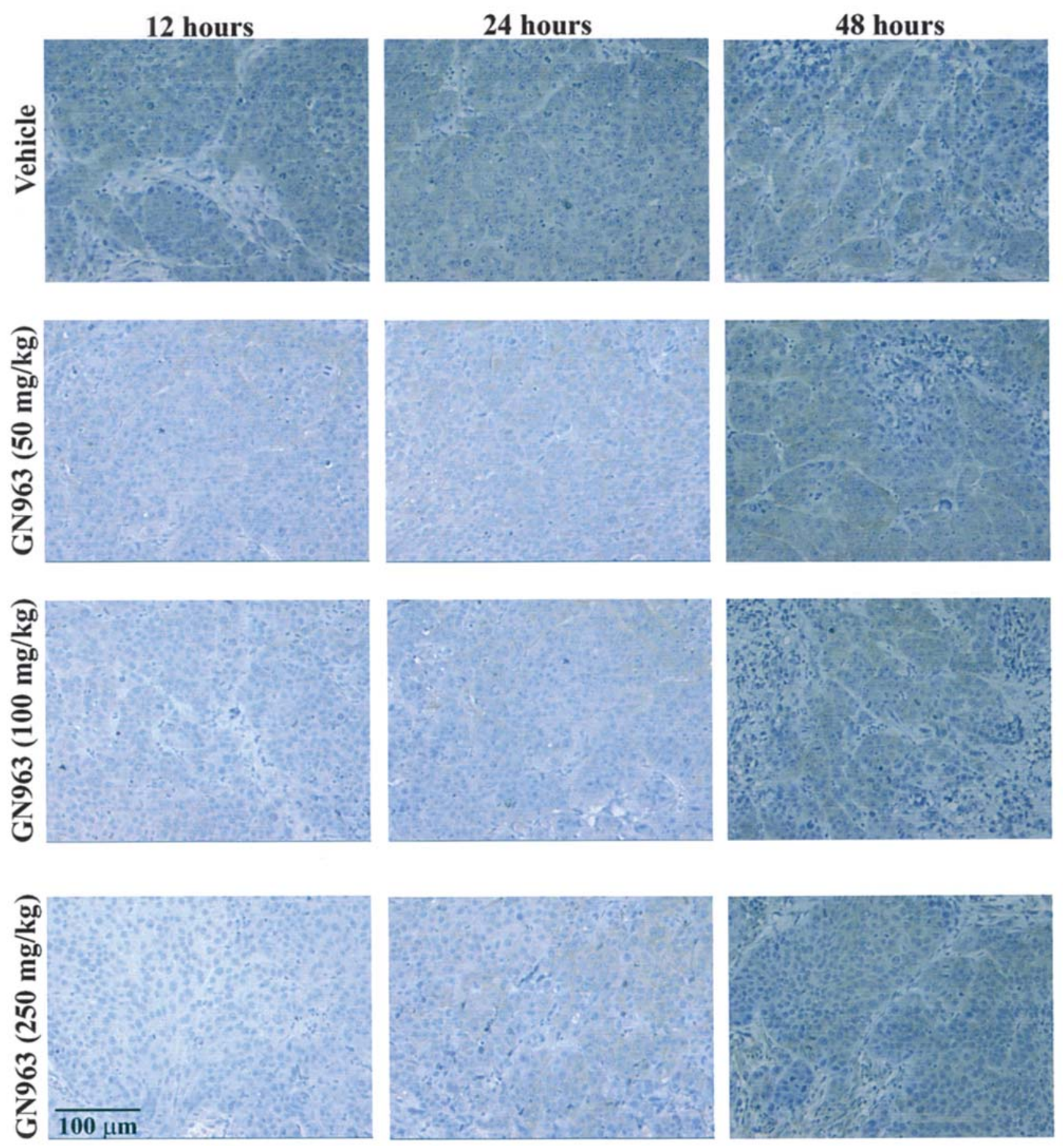

Figure 1. IHC detection of activated PDGFR- $\beta$ in pancreatic tumor sections after withdrawal of GN963. L3.6pl human pancreatic cancer cells were implanted into the pancreas of nude mice, and daily oral doses of 50,100, or $250 \mathrm{mg} / \mathrm{kg}$ GN963 were given for 2 consecutive days. Groups of mice ( $\mathrm{n}=5$ ) were sacrificed 15 or $30 \mathrm{~min}$ or 1, 2, 4, 8, 12, 48, or $72 \mathrm{~h}$ after cessation of therapy. The pancreatic lesions were harvested and processed for IHC, which showed that treatment with all doses of oral GN963 inhibited phosphorylation of PDGFR- $\beta$ for up to $48 \mathrm{~h}$.

ATP, $10 \mathrm{mM} \mathrm{Mg}^{2+}$, and $100 \mu \mathrm{M}$ sodium orthovanadate in $20 \mathrm{mM}$ HEPES buffer to each sample. To analyze the phosphorylation of an exogenous substrate, $10 \mu \mathrm{g} / \mu \mathrm{l}$ rabbit muscle enolase (Sigma-Aldrich, St. Louis, MO) was added to the reaction buffer. After $10 \mathrm{~min}$, reactions were terminated by the addition of SDS sample buffer. Proteins were separated by SDS-PAGE on $8 \%$ polyacrylamide gels, and radioactive proteins were detected by autoradiography.

\section{Results}

In vitro effect of GN963 on human pancreatic cancer cells. To determine the antiproliferative activity of GN963, L3.6pl human pancreatic cancer cells were cultured for 3 days in medium containing increasing concentrations of GN963 (0$500 \mu \mathrm{m})$. The MTT assay revealed that the $\mathrm{IC}_{50}$ was $150 \mu \mathrm{m}$ (data not shown). The high concentration necessary to achieve 
Table I. Treatment of orthotopically implanted L3.6pl human pancreatic cancer cells by GN963 and gemcitabine.

\begin{tabular}{|c|c|c|c|c|c|c|c|c|}
\hline \multirow[b]{3}{*}{ Treatment group ${ }^{\mathrm{a}}$} & \multirow{3}{*}{$\begin{array}{l}\text { Tumor } \\
\text { incidence }^{b}\end{array}$} & \multicolumn{4}{|c|}{ Pancreatic tumor } & \multirow{3}{*}{$\begin{array}{c}\text { Incidence } \\
\text { of liver } \\
\text { metastasis }^{\mathrm{b}}\end{array}$} & \multirow{2}{*}{\multicolumn{2}{|c|}{ Body weight (g) }} \\
\hline & & \multicolumn{2}{|c|}{ Tumor volume $\left(\mathrm{mm}^{3}\right)$} & \multicolumn{2}{|c|}{ Tumor weight (g) } & & & \\
\hline & & Median & Range & Median & Range & & Median & Range \\
\hline Vehicle control & $10 / 10$ & 1427.2 & $700.1-3651.2$ & 2.7 & $1.2-3.4$ & $8 / 10$ & 28 & $26-30$ \\
\hline Gemcitabine $(125 \mathrm{mg} / \mathrm{kg})$ & $10 / 10$ & 1109.5 & $729.2-3323.5$ & 1.3 & $1.7-2.8$ & $7 / 10$ & 30 & $22-34$ \\
\hline GN963 (50 mg/kg) & $10 / 10$ & $1097.5^{\mathrm{c}}$ & $534.0-1523.5$ & $1.0^{\mathrm{c}}$ & $0.8-1.1$ & $8 / 10$ & 29 & $24-32$ \\
\hline GN963 (100 mg/kg) & $10 / 10$ & $1043.2^{c}$ & $220.5-1672.3$ & $1.1^{\mathrm{c}}$ & $0.9-2.2$ & $3 / 10$ & 32 & $27-33$ \\
\hline GN963 (250 mg/kg) & $10 / 10$ & 1324.4 & $676.0-1568.3$ & 1.4 & $0.9-2.5$ & $2 / 10$ & 24 & $21-28$ \\
\hline $\begin{array}{l}\text { GN963 }(50 \mathrm{mg} / \mathrm{kg})+ \\
\text { gemcitabine }(125 \mathrm{mg} / \mathrm{kg})\end{array}$ & $10 / 10$ & $966.0^{c}$ & $134.5-2075.2$ & $0.9^{\mathrm{c}}$ & $0.5-1.7$ & $6 / 10$ & 26 & $24-28$ \\
\hline $\begin{array}{l}\text { GN963 }(100 \mathrm{mg} / \mathrm{kg})+ \\
\text { gemcitabine }(125 \mathrm{mg} / \mathrm{kg})\end{array}$ & $10 / 10$ & $702.1^{\mathrm{c}}$ & $79.2-998.5$ & $1.0^{\mathrm{c}}$ & $0.3-1.8$ & $3 / 10$ & 26 & $22-29$ \\
\hline $\begin{array}{l}\text { GN963 }(250 \mathrm{mg} / \mathrm{kg})+ \\
\text { gemcitabine }(125 \mathrm{mg} / \mathrm{kg})\end{array}$ & $10 / 10$ & $846.8^{c}$ & $520.5-1322.4$ & $0.8^{\mathrm{c}}$ & $0.5-1.4$ & $2 / 10$ & $22^{\mathrm{d}}$ & $21-27$ \\
\hline
\end{tabular}

an $\mathrm{IC}_{50}$ is probably due to the low levels of expression of PDGFRs by the L3.6pl cell line in vitro.

In vivo pharmacokinetics of GN963. Mice injected with L3.6pl human pancreatic cancer cells were treated orally with 50 , 100 , or $250 \mathrm{mg} / \mathrm{kg}$ GN963 or vehicle solution alone daily for 2 days and sacrificed at various times after the second treatment. IHC analysis of tumor tissue using specific antiPDGFR- $\beta$ and anti-PDGFR- $\beta-P$ antibodies revealed that treatment with oral GN963 at any of the three doses inhibited phosphorylation of PDGFR- $\beta$ for up to $48 \mathrm{~h}$ (Fig. 1). All tumors expressed similar levels of PDGFR- $\beta$ protein (data not shown). These data indicate that the inhibition of PDGFR- $\beta$ phosphorylation by GN963 requires oral administration of the drug every $48 \mathrm{~h}$.

Effect of GN963 dose on in vivo therapy of orthotopic human L3.6pl pancreatic tumors. We first evaluated the optimal biological dose and therapeutic efficacy of thrice-weekly oral administration of GN963 against human pancreatic cancer cells growing in the pancreas of nude mice. We also determined whether GN963 treatment is associated with downregulation of activated PDGFR- $\beta$ on the tumor cells and tumor-associated endothelial cells. L3.6pl cells were injected into the pancreas of nude mice. Seven days later, groups of mice $(n=10$ per group) began receiving thrice-weekly oral administration of vehicle solution alone, twice-weekly i.p. injection of $125 \mathrm{mg} / \mathrm{kg}$ gemcitabine, or thrice-weekly oral administration of 50, 100, or $250 \mathrm{mg} / \mathrm{kg}$ GN963 with or without concomitant twiceweekly i.p. injection of $125 \mathrm{mg} / \mathrm{kg}$ gemcitabine. The mice were treated for 4 weeks and then sacrificed and necropsied.
Detailed necropsy revealed that all of the mice had tumors in the pancreas (Table I). Thrice-weekly oral administration of single-agent GN963 at 50 or $100 \mathrm{mg} / \mathrm{kg}$ significantly decreased the median tumor volume compared with vehicleonly (control) treatment. Mice receiving twice-weekly i.p. single-agent gemcitabine or $250 \mathrm{mg} / \mathrm{kg}$ GN963 developed smaller pancreatic tumors than control mice, but the difference was not statistically significant. Interestingly, GN963 at 100 or $250 \mathrm{mg} / \mathrm{kg}$ significantly decreased the incidence of liver metastasis, whereas GN963 administered at $50 \mathrm{mg} / \mathrm{kg}$ did not. Furthermore, treatment with any dose of GN963 in combination with gemcitabine produced the greatest decreases in median volume of pancreatic tumors compared with control treatment. Once again, the incidence (as determined by dissecting microscope and histology) of liver metastasis was significantly lower in mice treated with 100 or $250 \mathrm{mg} / \mathrm{kg}$ GN963 combined with gemcitabine. No significant effects on the incidence of liver metastasis were observed with GN963 administered at $50 \mathrm{mg} / \mathrm{kg}$ combined with gemcitabine. Finally, treatment with GN963 administered alone was well tolerated by the mice, as indicated by maintenance of body weight (Table I). However, GN963 administered at $250 \mathrm{mg} / \mathrm{kg}$, combined with gemcitabine, significantly decreased body weight by $24 \%$. Considering the data on pancreatic tumor weight and volume, incidence of liver metastasis, and level of toxicity as measured by body weight, we concluded that the most effective and safe dose of GN963 was $100 \mathrm{mg} / \mathrm{kg}$.

To determine the biological effect of the three doses of GN963, administered alone or in combination with gemcitabine, pancreatic tumors from mice in all treatment groups were analyzed by IHC for expression of PDGFR- $\beta$ and 

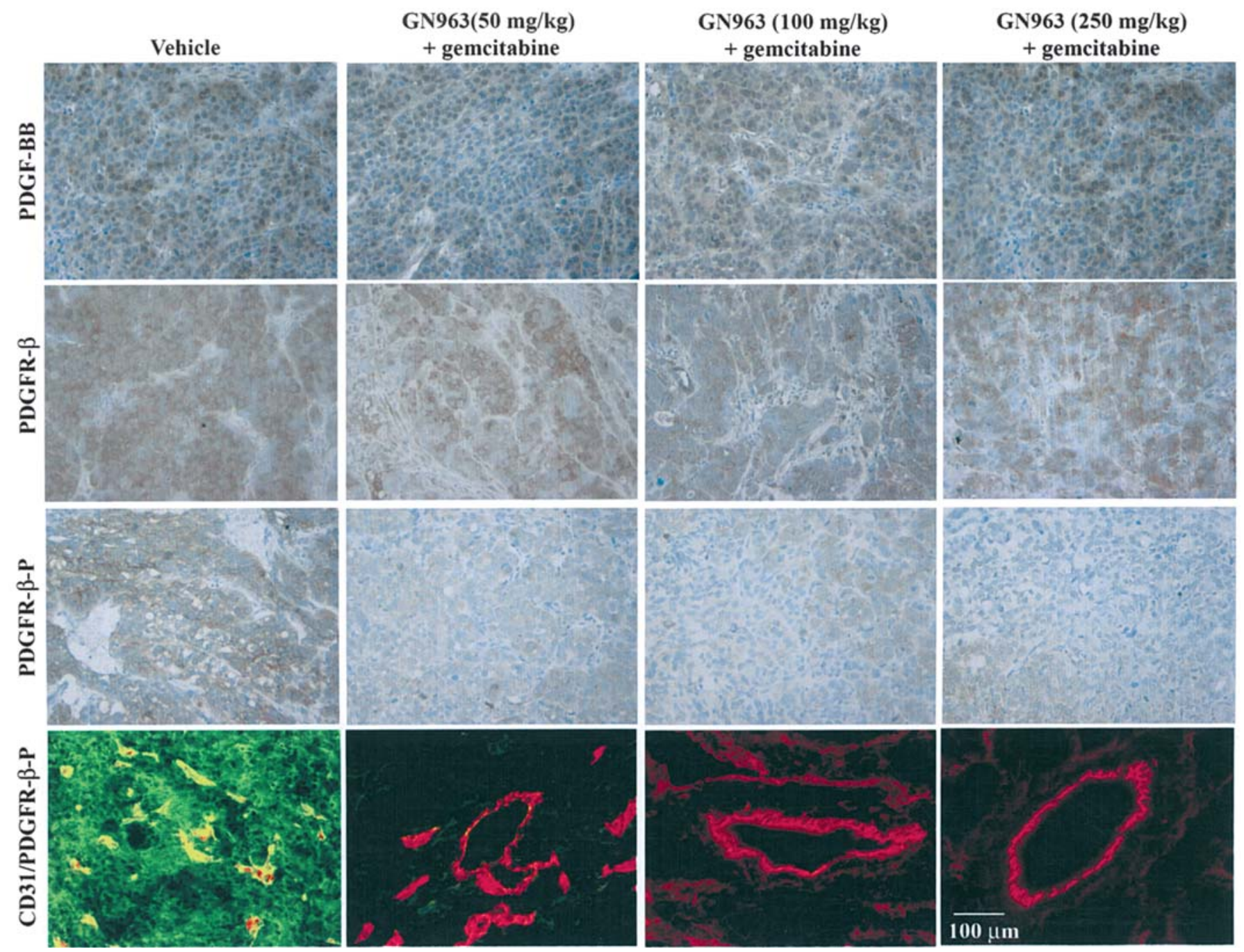

Figure 2. IHC detection of PDGF BB, PDGFR- $\beta$ and activated PDGFR- $\beta$. Pancreatic tumors were harvested from nude mice after 4 weeks of treatment with vehicle solution or thrice-weekly oral GN963 (three different doses) + twice-weekly i.p. gemcitabine. Pancreatic tumors in mice from all treatment groups had similar expression levels of PDGF BB and PDGFR- $\beta$. There was a significant decrease in activation of PDGFR- $\beta$ in tumors from mice treated with GN963. Frozen sections of the tumors were stained for PDGFR- $\beta-P$ (green) and the endothelial cell marker, CD31/PECAM (red). The expression of activated PDGFR- $\beta$ on tumor cells and tumor-associated endothelial cells was lower in all GN963 + gemcitabine treatment groups than in the control group. Yellow staining indicates PDGFR-B-P-positive endothelial cells.

activated PDGFR- $\beta$ on the tumor cells and tumor-associated endothelial cells. Tumors from all treatment groups appeared to have the same pattern of PDGF BB and PDGFR-B. However, the expression of activated PDGFR- $\beta$ was significantly reduced in tumors from mice treated with GN963 alone or in combination with gemcitabine than in tumors from mice treated with vehicle alone or gemcitabine alone. Fig. 2 shows the expression patterns in tumors from mice treated with GN963 in combination with gemcitabine.

In a previous study (12), we found that double immunofluorescence staining identified activated PDGFR- $\beta$ on endothelial cells in human pancreatic adenocarcinoma specimens and liver metastases from primary pancreatic cancer. We therefore used a double immunofluorescence staining technique to examine the expression of activated PDGFR- $\beta$ on endothelial cells in pancreatic tumors from mice in all treatment groups. Tumors from control (vehicle-treated) mice showed significant colocalization of CD31 and PDGFR-B-P (Fig. 2), indicating the presence of activated PDGFR- $\beta$ on endothelial cells. This expression was significantly lower in tumors from mice in all GN963 treatment groups (as compared to control mice). Not surprisingly, the lowest expression of activated PDGFR- $\beta$ by endothelial cells was found in tumors from mice treated with GN963 in combination with gemcitabine (Fig. 2).

Optimal biological dose of GN963 and gemcitabine for therapy. In the next set of experiments, we determined whether administration of the optimal biological dose of GN963 $(100 \mathrm{mg} / \mathrm{kg})$ combined with gemcitabine would produce additive or synergistic therapeutic effects on pancreatic tumors. Groups of nude mice ( $\mathrm{n}=10$ per group) received injection of L3.6pl human pancreatic cancer cells into the pancreas. One week later, when the tumors were well established, the mice began receiving thrice-weekly oral administration of vehicle solution (control group), twice-weekly i.p. injection of $100 \mathrm{mg} / \mathrm{kg}$ gemcitabine alone, thrice-weekly oral administration of $100 \mathrm{mg} / \mathrm{kg}$ GN963, or GN963 combined with gemcitabine. The mice were treated for 4 weeks, at which time all mice were sacrificed and necropsied. The data from one representative experiment (of two) are summarized in Table II. There 
Table II. Therapy of L3.6pl human pancreatic adenocarcinoma cells growing in the pancreas of nude mice.

\begin{tabular}{|c|c|c|c|c|c|c|c|c|}
\hline \multirow[b]{3}{*}{ Treatment group ${ }^{\mathrm{a}}$} & \multirow{3}{*}{$\begin{array}{l}\text { Tumor } \\
\text { incidence }^{\mathrm{b}}\end{array}$} & \multicolumn{4}{|c|}{ Pancreatic tumors } & \multirow{3}{*}{$\begin{array}{l}\text { Incidence } \\
\text { of liver } \\
\text { metastasis }^{\mathrm{b}}\end{array}$} & \multirow{2}{*}{\multicolumn{2}{|c|}{ Body weight $(\mathrm{g})$}} \\
\hline & & \multicolumn{2}{|c|}{ Tumor volume $\left(\mathrm{mm}^{3}\right)$} & \multicolumn{2}{|c|}{ Tumor weight (g) } & & & \\
\hline & & Median & Range & Median & Range & & Median & Range \\
\hline Vehicle control & $10 / 10$ & 1765.7 & $758.2-2331.1$ & 1.5 & $0.7-2.8$ & $6 / 10$ & 30 & $22-34$ \\
\hline Gemcitabine $(100 \mathrm{mg} / \mathrm{kg})$ & $10 / 10$ & 1030.0 & $546.7-1872.7$ & 0.8 & $0.4-1.9$ & $5 / 10$ & 28 & $22-34$ \\
\hline GN963 (100 mg/kg) & $10 / 10$ & $839.0^{\mathrm{c}, \mathrm{d}}$ & $84.5-1922.5$ & $0.7^{\mathrm{c}, \mathrm{d}}$ & $0.2-1.2$ & $1 / 10$ & 25 & $23-28$ \\
\hline $\begin{array}{l}\text { GN963 }(100 \mathrm{mg} / \mathrm{kg})+ \\
\text { gemcitabine }(100 \mathrm{mg} / \mathrm{kg})\end{array}$ & $10 / 10$ & $330.0^{\mathrm{e}}$ & $105.9-526.5$ & $0.4^{\mathrm{e}}$ & $0.3-0.9$ & $0 / 10$ & 28 & $21-30$ \\
\hline
\end{tabular}

${ }^{\mathrm{a}} \mathrm{L} 3.6 \mathrm{pl}$ human pancreatic cancer cells $\left(1 \times 10^{6}\right)$ were injected into the pancreas of nude mice. Seven days later, groups of mice were treated with vehicle solution, twice-weekly i.p. gemcitabine $(100 \mathrm{mg} / \mathrm{kg})$, thrice-weekly oral GN963 (100 mg/kg), or combination of gemcitabine $(100 \mathrm{mg} / \mathrm{kg})$ and GN963 (100 mg/kg). All mice were sacrificed on day 35. ${ }^{b}$ Number of positive mice/number of mice injected. ${ }^{c} \mathrm{P}<0.005$ compared to control. ${ }^{\mathrm{d}}<0.4$ compared to gemcitabine alone. ${ }^{\mathrm{e}} \mathrm{P}<0.0005$ compared to control or gemcitabine alone.

Table III. IHC analysis of dividing tumor cells, endothelial cells and apoptotic endothelial cells, after treatment with GN963 and gemcitabine.

\begin{tabular}{|c|c|c|c|c|c|}
\hline \multirow[b]{2}{*}{ Treatment group ${ }^{\mathrm{a}}$} & \multicolumn{3}{|c|}{ Tumor cells } & \multicolumn{2}{|c|}{ Endothelial cells } \\
\hline & PDGFR- $\beta^{+b}$ & PDGFR- $\beta-\mathrm{P}^{+\mathrm{b}}$ & $\overline{\mathrm{PCNA}^{+\mathrm{c}}}$ & $\mathrm{CD}^{2} 1^{+\mathrm{d}}$ & $\% \mathrm{TUNEL}^{+\mathrm{e}}$ \\
\hline Vehicle control & $298 \pm 28$ & $125 \pm 20$ & $489 \pm 38$ & $62 \pm 3$ & $0 \pm 0$ \\
\hline Gemcitabine (100 mg/kg) & $322 \pm 21$ & $112 \pm 16$ & $198 \pm 17$ & $32 \pm 2$ & $2 \pm 1$ \\
\hline GN963 (100 mg/kg) & $289 \pm 26$ & $40 \pm 11^{\mathrm{f}}$ & $36 \pm 8^{\mathrm{f}}$ & $7 \pm 3^{f}$ & $8 \pm 4^{f}$ \\
\hline $\begin{array}{l}\text { GN963 }(100 \mathrm{mg} / \mathrm{kg})+ \\
\text { gemcitabine }(100 \mathrm{mg} / \mathrm{kg})\end{array}$ & $300 \pm 25$ & $28 \pm 7^{f}$ & $18 \pm 4^{\mathrm{f}}$ & $3 \pm 1^{\mathrm{f}}$ & $12 \pm 8^{\mathrm{f}}$ \\
\hline
\end{tabular}

${ }^{\mathrm{a}} \mathrm{L} 3.6 \mathrm{pl}$ human pancreatic cancer cells $\left(1 \times 10^{6}\right)$ were injected into the pancreas of nude mice. Seven days later, groups of mice were treated with vehicle solution, twice-weekly i.p. gemcitabine (100 mg/kg), thrice-weekly oral GN963 (100 mg/kg), or gemcitabine (100 mg/kg) and GN963 (100 mg/kg). All mice were sacrificed on day 35. ${ }^{b}$ Mean \pm SD absorbance, determined as described in Materials and methods. ${ }^{\mathrm{c} N u m b e r}\left(\right.$ mean $\pm \mathrm{SD}$ ) of $\mathrm{PCNA}^{+}$tumor cells per field in 10 random $0.159-\mathrm{mm}^{2}$ fields at $\mathrm{x} 100$ magnification. ${ }^{\mathrm{N} N u m b e r}(\mathrm{mean} \pm \mathrm{SD})$ of

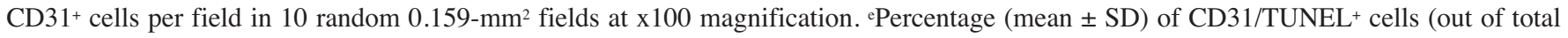
number of cells) in 10 random $0.011-\mathrm{mm}^{2}$ fields at $\mathrm{x} 400$ magnification. ${ }^{\mathrm{f}} \mathrm{P}<0.005$ compared to control

were no significant changes in body weight in any of the treatment groups. Treatment with gemcitabine alone did not result in significantly lower pancreatic tumor volumes compared with control treatment. Mice treated with singleagent GN963 had significantly smaller pancreatic tumors than did control mice, but the most significant difference in pancreatic tumor volumes was observed between control mice and mice treated with GN963 and gemcitabine.

To further characterize and determine the biological effects

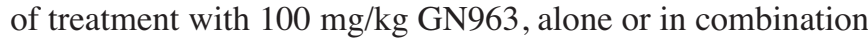
with gemcitabine, pancreatic tumors from mice in different treatment groups were processed as either paraffin-embedded or frozen sections for IHC. All tumors were analyzed for expression of PDGFR- $\beta$ activated PDGFR- $\beta$ and CD31/ PDGFR- $\beta-P$. Tumors from all mice expressed similar levels of PDGFR- $\beta$. The expression of activated PDGFR- $\beta$, however, was significantly lower in tumors from mice treated with GN963, both alone and combined with gemcitabine, than in tumors from control mice (Fig. 3). Immunofluorescence double-labeling of tumors for CD31 expression and PDGFR$\beta-P$ revealed colocalization in endothelial cells in tumors from mice treated with vehicle or gemcitabine alone. Endothelial cells in tumors of mice treated with GN963 alone or in combination with gemcitabine expressed significantly lower levels of PDGFR- $\beta$ on their surfaces.

We also analyzed cell proliferation, microvessel density, and endothelial cell apoptosis using anti-PCNA and anti-CD31/ PECAM-1 antibodies and CD31/TUNEL double labeling, respectively. The IHC data summarized in Table III show that the inhibition of tumor growth observed in mice treated with thrice-weekly oral GN963, alone or in combination with twice-weekly i.p. gemcitabine, was accompanied by a significant reduction in tumor cell proliferation and tumor vascularization. The number of proliferating tumor cells and the density of microvessels were significantly lower in tumors from control mice than in tumors from mice treated with the 

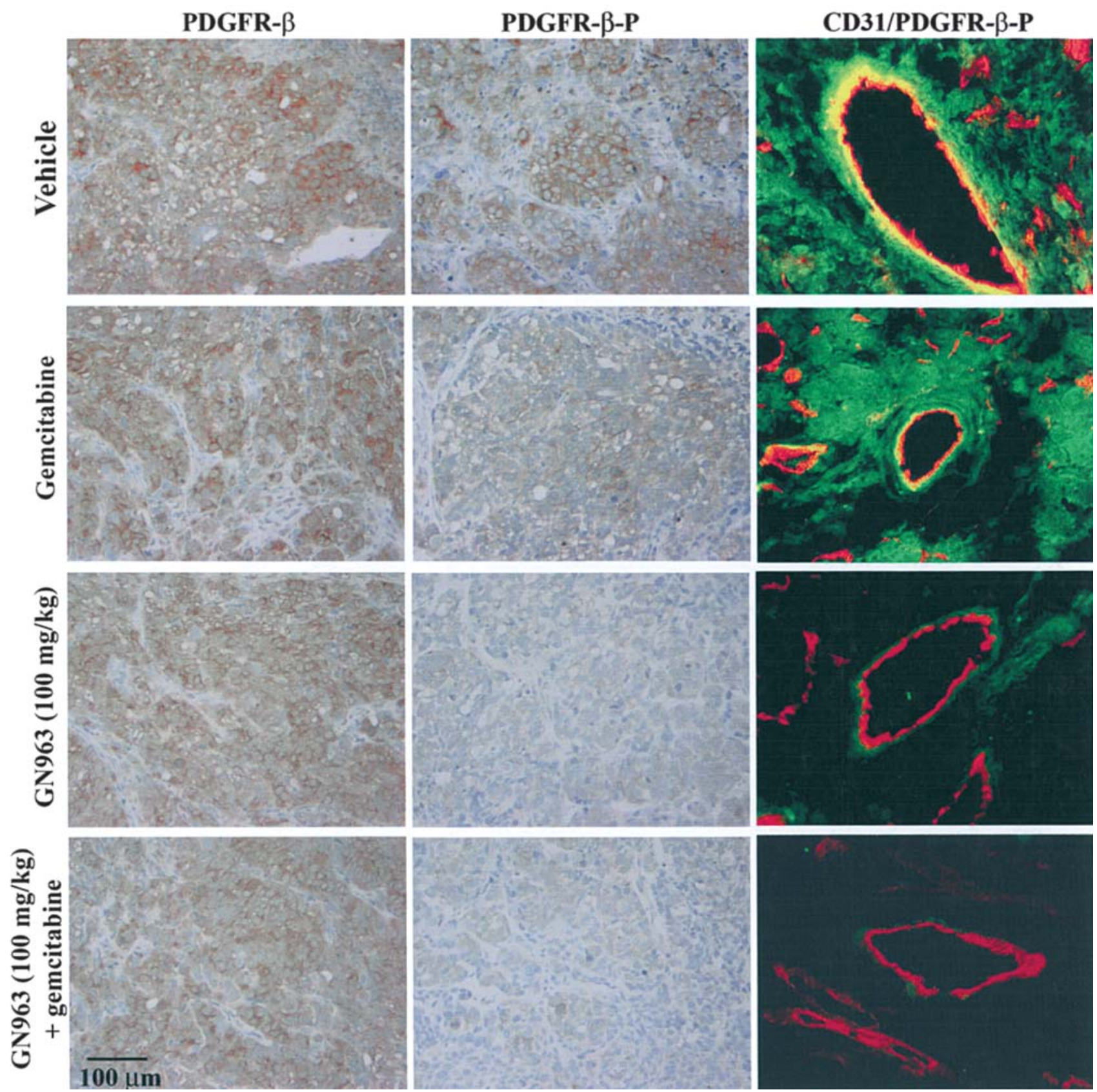

Figure 3. IHC detection of PDGFR- $\beta$ and activated PDGFR- $\beta$ and immunofluorescence double-labeling analysis of pancreatic tumors in an orthotopic nude mouse model treated with GN963. Pancreatic tumors were harvested from nude mice after 4 weeks of treatment with vehicle solution, twice-weekly i.p. gemcitabine alone, thrice-weekly oral GN963 (100 mg/kg) alone, or a combination of GN963 + gemcitabine. The expression level of PDGFR- 3 was similar among all treatment groups. The expression level of activated PDGFR- $\beta$ in the tumor cells and tumor-associated endothelial cells was significantly decreased in tumors from mice treated with GN963. Frozen tumor sections were stained for activated PDGFR-ß-P (green) or CD31 (red). Yellow indicates PDGFR-ß-Ppositive endothelial cells, which were seen only in mice treated with vehicle or single-agent gemcitabine.

combination therapy (Fig. 4 and Table III). Finally, tumors from mice treated with GN963 alone or in combination with gemcitabine had a significantly greater percentage of apoptotic endothelial cells than tumors from gemcitabine-treated or control mice.

Inhibition of Src and Akt phosphorylation. The observation that Src can be activated in response to PDGF suggests that it contributes to PDGF-dependent responses (39,53-57). Src is activated in more than $70 \%$ of primary human pancreatic adenocarcinomas (58) and several studies have demonstrated that Src activity can directly or indirectly regulate members of the MAP kinase family as well as PI3 kinase activity $(42,43,45,59-61)$. Therefore, we next examined the ability of the PDGFR inhibitor, GN963, to inactivate Src and Akt (as a $\mathrm{PI} 3 \mathrm{~K}$ kinase substrate) signaling. In vitro treatment of L3.6pl cells with increasing doses of GN963 $(0-300 \mu \mathrm{M})$ reduced the amount of activated PDGFR- $\beta$, activated Src and activated Akt (Fig. 5A), suggesting a link between the effects of GN963 at the membrane level and activated Src-induced control of PDGFR signaling pathways. The minor increase in the activity of Src and Akt upon stimulation with PDGF BB illustrates that there are constitutively high levels of activated Src (and Akt) in L3.6pl human pancreatic cancer cells. Moreover, there 

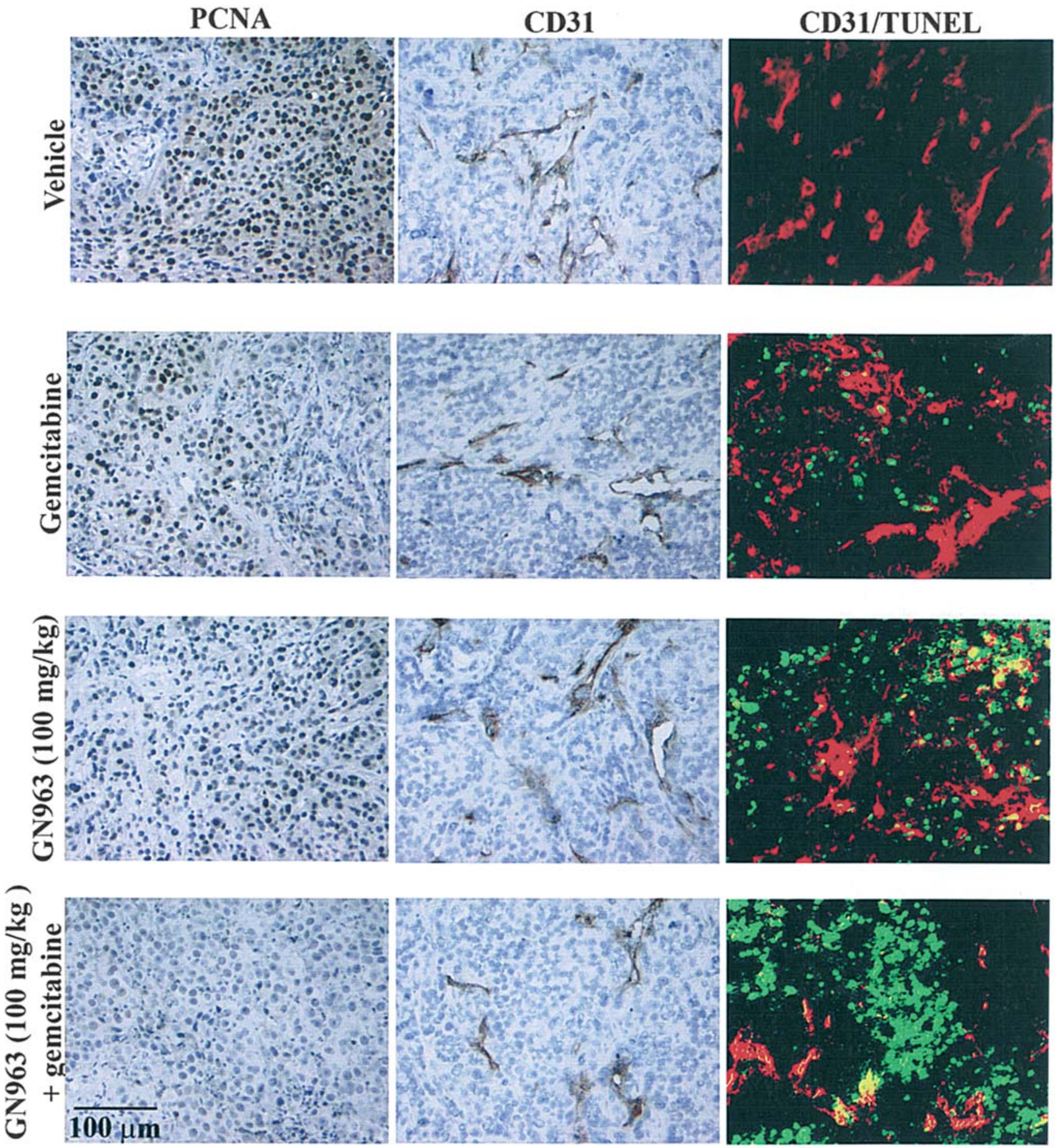

Figure 4. IHC analysis of cell proliferation, microvessel density, and tumor and endothelial cell apoptosis in L3.6pl pancreatic tumors from mice treated with GN963 and/or gemcitabine. Pancreatic tumors were harvested after 4 weeks of treatment, and sections were stained for PCNA or CD31/PECAM-1 (brown) or double-labeled for CD31 (red) and TUNEL (green). Tumors from mice treated with GN963 alone or with GN963 + gemcitabine had markedly fewer PCNApositive cells and CD31-positive endothelial cells, in direct relation to the induction of apoptosis. Yellow indicates apoptotic endothelial cells.

appears to be constitutively activated PDGFR- $\beta$ (albeit to a lesser degree in vitro than in vivo), which could contribute to the high levels of activated Src. The level of PDGFR, Src or Akt protein did not vary in response to treatment. Moreover, exposure of the cells to GN963 caused a dose-dependent reduction in Src activity, as shown by an immunocomplex kinase assay (Fig. 5B).

To demonstrate the ability of GN963 to disrupt Src and $\mathrm{PI} 3 \mathrm{~K} / \mathrm{Akt}$ activity in vivo, we examined the expression of Src, activated $\mathrm{Src}(\mathrm{P}-\mathrm{Src})$, and activated Akt (P-Akt) on pancreatic tumor cells growing in the pancreas of nude mice. Consistent with the in vitro results, IHC analyses revealed that activated Src and activated Akt were reduced in pancreatic tumors treated with GN963, alone or in combination with gemcitabine (Fig. 6).

\section{Discussion}

Several studies emphasize the significant contribution of PDGFR signaling and Src activation to the progressive growth of human pancreatic cancer and provide a rationale 
A

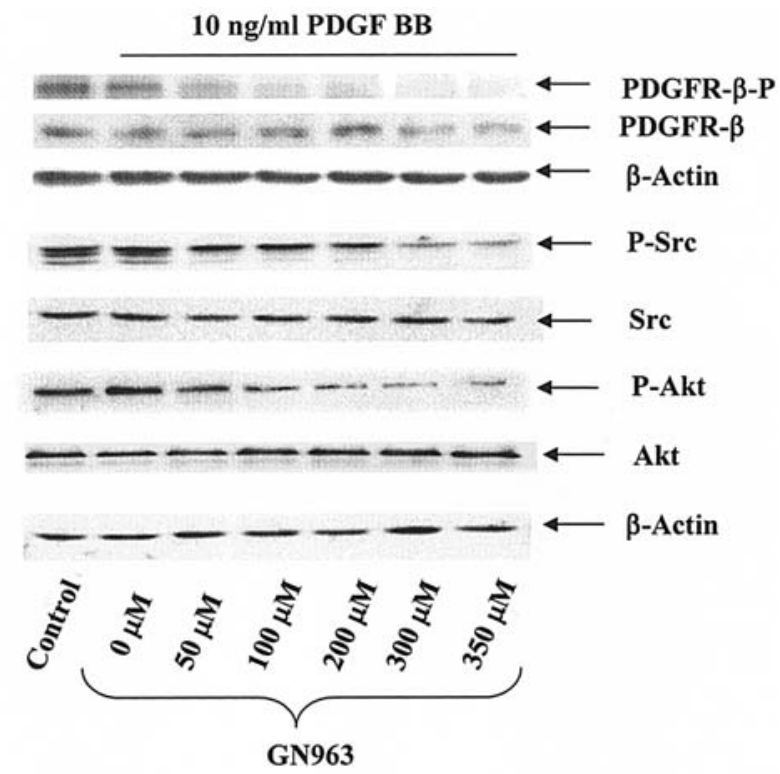

B

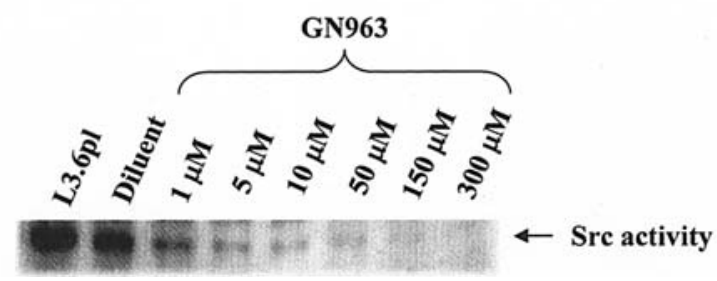

Figure 5. In vitro PDGFR, Src, and Akt Activity. A, inhibition of PDGFR, Src, and Akt activity by GN963. L3.6pl human pancreatic carcinoma cells were incubated for $60 \mathrm{~min}$ in serum-free medium (control) or medium containing 0-350 $\mu \mathrm{M}$ GN963. Cultures were then stimulated for $15 \mathrm{~min}$ with PDGF BB, washed, and refed with serum-free medium. The levels of PDGFR protein, Src protein, P-Src, Akt protein, and P-Akt were determined by Western blotting. Expression of PDGFR, Src, or Akt did not vary among the groups, but GN963 inhibited the phosphorylation of Src and Akt. B, inhibitory effect of increasing concentrations of GN963 on Src kinase activity in L3.6pl human pancreatic carcinoma cells. Cell lysates containing $500 \mu \mathrm{g}$ of protein were incubated with anti-Src antibody, and immune kinase complex assays were performed as described in Materials and methods.

for selecting inhibitors of the PDGFR and Src kinases. In addition, recent reports have shown that Src regulates pancreatic tumor progression through the activation of several key signaling molecules, including Akt and Erk-1/2/MAPK, which are essential for pancreatic tumor cell survival and increased metastatic potential (40-46). In the present study, we confirm that targeting the PDGFR on pancreatic tumor cells and tumor-associated endothelial cells can produce significant therapeutic benefits. Oral administration of GN963, a novel PDGFR inhibitor, significantly inhibited the phosphorylation of PDGFR- $\beta$ (but not the expression of PDGF BB and PDGFR- $\beta$ ) on pancreatic tumor cells and tumor-associated endothelial cells. Also, the activity of Src and Akt were significantly reduced in pancreatic tumors treated with this novel PDGFR inhibitor.

In a previous study of ours, IHC analysis revealed that all human pancreatic adenocarcinoma specimens tested were positive for PDGF ligands and receptors, that $>90 \%$ of pancreatic cancer expressed activated PDGFR, but that only $10 \%$ of adjacent nonmalignant pancreatic tissue samples were positive for activated PDGFR (12). Furthermore, levels of PDGFR- $\alpha$ and PDGFR- $\beta$ in lysates obtained from pancreatic tumors growing in the pancreas of nude mice were higher than levels in cultured cancer cells, implying that the tumor microenvironment and in vivo mechanisms are responsible for an autocrine loop that promotes the growth of pancreatic cancer $(8,13)$. In addition, the presence of activated PDGFR on endothelial cells in human pancreatic cancer specimens indicates a paracrine mechanism of activation (12).

In this study, we show that, under in vitro and in vivo conditions, control and GN963-treated L3.6pl human pancreatic cancer cells expressed similar levels of activated PDGFR and Src, but treatment with GN963 inhibited the activation of PDGFR and Src. The PDGFR on tumor cells was rephosphorylated $48 \mathrm{~h}$ after cessation of GN963 treatment (Fig. 1).

All three doses $(50,100$ and $250 \mathrm{mg} / \mathrm{kg})$ of oral GN963, administered thrice-weekly in combination with twice-weekly gemcitabine, produced equivalent therapeutic effects against primary tumors (Table I). The most significant decrease in the incidence of liver metastasis was produced by GN963 at does of 100 and $250 \mathrm{mg} / \mathrm{kg}$. However, the administration of $250 \mathrm{mg} / \mathrm{kg}$ GN963 in combination with gemcitabine produced a $24 \%$ loss in body weight, whereas GN963 at $100 \mathrm{mg} / \mathrm{kg}$ did not. Therefore, we chose GN963 at $100 \mathrm{mg} / \mathrm{kg}$ as the optimal biologically effective dose (Table I).

L3.6pl cells growing in the pancreas of nude mice were relatively resistant to treatment with gemcitabine (Table II). The combination of gemcitabine with the optimal biological dose of GN963 (100 mg/kg) reduced tumor growth by nearly $81 \%(\mathrm{P}<0.00055)$. This therapeutic effect was significantly better than that of treatment with GN963 alone $(52 \%, \mathrm{P}<0.005)$. In addition, GN963 plus gemcitabine completely inhibited the incidence of liver metastasis. Oral treatment with GN963 inhibited the phosphorylation of PDGFR- $\beta$ (but not its expression) on tumor cells and tumor-associated endothelial cells. Compared to control mice, mice treated with GN963 plus gemcitabine had significantly fewer proliferating tumor cells and significantly higher apoptosis of tumor and tumorassociated endothelial cells, leading to decreased microvessel density.

Preclinical studies of human pancreatic cancer have demonstrated that the antitumor efficacy of gemcitabine can be enhanced by additional treatment with inhibitors of tyrosine kinase receptors $(12,17-21)$. Activation of PDGFR has been shown to activate Src and PI3K/Akt signaling, which causes an increase in resistance to apoptosis and thereby serves as a survival mechanism for tumor-associated endothelial cells $(53,62-65)$. Tumor-associated endothelial cells divide up to 2,000 times faster than endothelial cells of normal tissue (66); inhibition of their survival mechanisms by the PDGFR inhibitor, GN963, would make them more susceptible to chemotherapy. We therefore hypothesize that inhibition of Src and Akt kinase function through PDGFR inhibition will enhance the antitumor effect of gemcitabine in pancreatic cancer. Indeed, in the present study, treatment of pancreatic cancer cells growing in the pancreas of nude mice with GN963 increased their sensitivity to the anticycling agent, gemcitabine, thereby supporting the hypothesis that PDGF is a survival factor for tumor cells and tumor-associated endothelial cells. Even more notable was the finding that treatment 

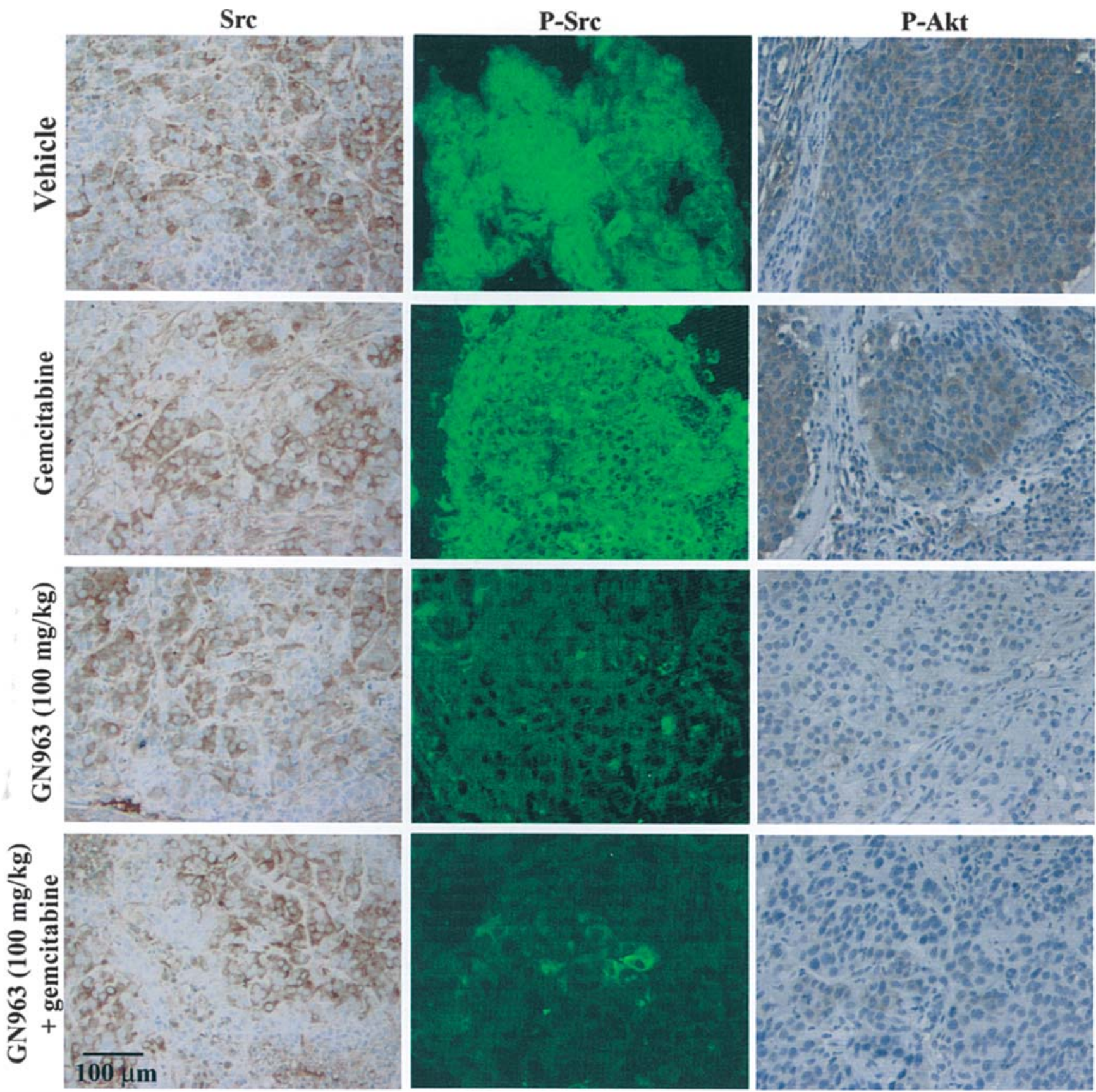

Figure 6. IHC detection of Src, activated Src, and activated Akt on tumor cells in L3.6pl pancreatic tumors from mice treated with GN963 and/or gemcitabine. Pancreatic tumors were harvested after 4 weeks of treatment, and sections were stained for Src (DAB), P-Src (green), and P-Akt (DAB). Tumors from all treatment groups stained positively for Src, but only tumors from mice treated with vehicle or gemcitabine alone stained positively for P-Src. Tumor cells from mice treated with GN963 alone or in combination with gemcitabine had significantly lower expression of P-Akt.

with GN963 alone or in combination with gemcitabine resulted in significantly lower levels of activated Src and Akt on pancreatic tumor cells (Fig. 6).

Our current results are the first to show that the PDGFR tyrosine kinase inhibitor, GN963, has an inhibitory effect on human pancreatic cancer growing in the pancreas of nude mice. Furthermore, the levels of activated Src and Akt were significantly decreased. Whether these effects were due to direct or indirect mechanisms remains unclear. Nonetheless, Src has emerged as an attractive candidate molecule for targeted therapies, and several small-molecule inhibitors of Src family kinases have been developed $(40-46,67,68)$ to inhibit pancreatic tumor growth and metastasis, with an emphasis on combination therapies with standard chemotherapeutic agents (46). The data from those studies, coupled with the data presented here, suggest that the inhibition of Src and Akt subsequent to PDGFR inhibition represents an important target for therapy for human pancreatic cancer.

In summary, human pancreatic cancer cells growing in the pancreas of nude mice produce high levels of PDGF, which can activate the PDGFR on both tumor cells (autocrine) and tumor-associated endothelial cells (paracrine). The selective inhibition of PDGFR with GN963 can nullify PDGF-induced activation of PDGFR and downstream signaling and, moreover, can significantly sensitize pancreatic cancer cells and the tumor vasculature to the cytotoxic effects of gemcitabine. In addition, 
interfering with Src and Akt activity could result in the repression of other molecules required for invasion and metastasis. Collectively, our findings recommend further development of GN963 as a therapy for human pancreatic cancer.

\section{Acknowledgements}

We thank Arminda Martinez (U.T. M. D. Anderson Cancer Center) and Donna Schade (Cancer Research Institute of M. D. Anderson Cancer Center Orlando) for help in preparing this manuscript.

\section{References}

1. Evans DB, Abbruzzese JL and Willett CG: Cancer of the pancreas. In: Cancer - Principles and Practice of Oncology. DeVita VT Jr, Hellman S, Rosenberg SA (eds). 6th edition. Lippincott Williams \& Wilkins, Philadelphia, pp1126-1161, 2001.

2. Burris H III, Moore M, Andersen J, Green M, Rothenberg M, Modiano M, Cripps M, Portenoy R, Storniolo A, Tarassoff P, Nelson R, Dorr F, Stephens C and Von Hoff D: Improvements in survival and clinical benefit with gemcitabine as first-line therapy for patients with advanced pancreas cancer: a randomized trial. J Clin Oncol 15: 2403-2413, 1997.

3. Moore M: Activity of gemcitabine in patients with advanced pancreatic carcinoma: A review. Cancer Res 78: 633-638, 1996.

4. Smith JJ, Derynck R and Korc M: Production of transforming growth factor in human pancreatic cancer cells: evidence for a superagonist autocrine cycle. Proc Natl Acad Sci USA 84: 7567-7570, 1987

5. Korc M, Chandrasekar B, Yamanaka Y, Friess H, Buchier M and Beger HG: Overexpression of the epidermal growth factor receptor in human pancreatic cancer is associated with concomitant increases in the levels of epidermal growth factor and transforming growth factor $\alpha$. J Clin Invest 90: 1352-1360, 1993.

6. Ebert M, Yokoyama M, Kobrin MS, Friess H, Lopez ME, Buchler MW, Johnson GR and Korc M: Induction and expression of amphiregulin in human pancreatic cancer. Cancer Res 54: 3959-3962, 1994

7. Kobrin MS, Funatomi H, Friess H, Buchler MW, Stathis P and Korc M: Induction and expression of heparin-binding EGF-like growth factor in human pancreatic cancer. Biochem Biophys Res Commun 202: 1705-1709, 1994.

8. Yamanaka Y, Friess H, Kobrin MS, Buchler M, Beger HG and Korc M: Coexpression of epidermal growth factor receptor and ligands in human pancreatic cancer is associated with enhanced tumor aggressiveness. Anticancer Res 13: 565-569, 1993.

9. Yokoi K, Sasaki T, Bucana CD, Fan D, Baker CH, Kitadai Y, Kuwai, Abbruzzese JL and Fidler IJ: Simultaneous inhibition of EGFR, VEGF and Platelet-derived growth factor receptor signaling combined with gemcitabine produces therapy of human pancreatic carcinoma and prolongs survival in an orthotopic nude mouse model. Cancer Res 22: 10371-10380, 2005.

10. Brown LF, Berse B, Jackman RW, Tognazzi K, Manseau EJ, Senger DR and Dvorak HF: Expression of vascular permeability factor (vascular endothelial growth factor) and its receptors in adenocarcinomas of the gastrointestinal tract. Cancer Res 53: 4727-4735, 1993.

11. Itakura J, Ishiwata T, Shen B, Kornmann M and Korc M: Concomitant over-expression of vascular endothelial growth factor and its receptors in pancreatic cancer. Int J Cancer 85: 27-34, 2000.

12. Hwang RF, Yokoi K, Bucana CD, Tsan R, Killion KK, Evans DB and Fidler IJ: Inhibition of platelet-derived growth factor receptor phosphorylation by STI571 (Gleevec) reduces growth and metastasis of human pancreatic carcinoma in an orthotopic nude mouse model. Clin Cancer Res 9: 6534-6544, 2003.

13. Ebert M, Yokoyama M, Friess H, Kobrin MS, Buchler MW and Korc M: Induction of platelet-derived growth factor A and B chains and over-expression of their receptors in human pancreatic cancer. Int J Cancer 62: 529-535, 1995.
14. Ostman A: PDGF receptor-mediators of autocrine tumor growth and regulators of tumor vasculature and stroma. Cytokine Growth Factor Rev 4: 275-286, 2004.

15. Ciardiello F, Bianco R, Caputo R, Caputo R, Damiano V, Troiani T, Melisi D, De Vita F, De Placido S, Bianco AR and Tortora G: Antitumor activity of ZD6474, a vascular endothelial growth factor receptor tyrosine kinase inhibitor, in human cancer cells with acquired resistance to antiepidermal growth factor receptor therapy. Clin Cancer Res 10: 784-793, 2004.

16. Bruns CJ, Shrader M, Harbison MT, Portera C, Solorzano CC, Jauch KW, Hicklin DJ, Radinsky R and Ellis LM: Effect of the vascular endothelial growth factor receptor-2 antibody DC101 plus gemcitabine on growth, metastasis and angiogenesis of human pancreatic cancer growing orthotopically in nude mice. Int J Cancer 102: 101-108, 2002.

17. Bruns CJ, Solorzano CC, Harbison MT, Ozawa S, Tsan R, Fan D, Abbruzzese J, Traxler P, Buchdunger E, Radinsky R and Fidler IJ: Blockade of the epidermal growth factor receptor signaling by a novel tyrosine kinase inhibitor leads to apoptosis of endothelial cells and therapy of human pancreatic carcinoma. Cancer Res 60: 2926-2935, 2000.

18. Solorzano CC, Baker CH, Tsan R, Traxler P, Cohen P, Buchdunger E, Killion JJ and Fidler IJ: Optimization for the blockade of the epidermal growth factor receptor signaling for therapy of human pancreatic carcinoma. Clin Cancer Res 8: 2563-2572, 2001

19. Solorzano CC, Baker CH, Bruns CJ, Killion JJ, Ellis LM, Wood $\mathrm{J}$ and Fidler IJ: Inhibition of growth and metastasis of human pancreatic cancer growing in nude mice by PTK $787 /$ ZK222584, an inhibitor of the vascular endothelial growth factor receptor tyrosine kinases. Cancer Biother Radiopharm 16: 359-370, 2001.

20. Baker CH, Solorzano CC and Fidler IJ: Blockade of vascular endothelial growth factor receptor and epidermal growth factor receptor signaling for therapy of metastatic human pancreatic cancer. Cancer Res 7: 1996-2003, 2002.

21. Baker CH, Kedar D, McCarty MF, Tsan R, Weber KL, Bucana CD and Fidler IJ: Blockade of epidermal growth factor receptor signaling on tumor cells and tumor-associated endothelial cells for therapy of human carcinomas. Am J Pathol 3: 929-938, 2002.

22. Ng SS, Tsao MS, Nicklee T and Hedley DW: Wortmannin inhibits pkb/akt phosphorylation and promotes gemcitabine antitumor activity in orthotopic human pancreatic cancer xenografts in immuno-deficient mice. Clin Cancer Res 10: 3269-3275, 2001.

23. Guba M, von Breitenbuch P, Steinbauer M, Koehl G, Flegel S, Hornung M, Bruns CJ, Zuelke C, Farkas S, Anthuber M, Jauch KW and Geissler EK: Rapamycin inhibits primary and metastatic tumor growth by antiangiogenesis: involvement of vascular endothelial growth factor. Nat Med 2: 128-135, 2002.

24. Parsons SJ and Parsons JT: Src family kinases, key regulators of signal transduction. Oncogene 23: 7906-7909, 2004.

25. Abram CL and Courtneidge SA: Src family tyrosine kinases and growth factor signaling. Exp Cell Res 254: 1-13, 2000.

26. Windham TC, Parikh NU, Siwak DR, Summy JM, McConkey DJ, Kraker AJ and Gallick GE: Src activation regulates anoikis in human colon tumor cell lines. Oncogene 21: 7797-7807, 2002.

27. Hair J, Gallick GE and Nicholson GL: Src protein kinase pp60csrc influences adhesion stabilization of HT-29 colon carcinoma cells to extracellular matrix components under dynamic conditions of laminar flow. J Exp Ther Oncol 2: 237-245, 2002.

28. Myoui A, Nishimura R, Williams PJ, Hiraga T, Tamura D, Michigami T, Mundy GR and Yoneda T: C-SRC tyrosine kinase activity is associated with tumor colonization in bone and lung in an animal model of human breast cancer metastasis. Cancer Res 63: 5028-5033, 2003.

29. Lu Y, Yu Q, Liu JH, Zhang J, Wang H, Koul D, McMurray JS, Fang X, Yung WK, Siminovitch KA and Mills GB: Src family protein-tyrosine kinases alter the functions of PTEN to regulate phosphatidylinositol 3-kinase/AKT cascades. J Biol Chem 278: 40057-40066, 2003.

30. Lutz MP, Esser IB, Flossmann-Kast BB, Vogelmann R, Luhrs H, Friess H, Buchler MW and Adler G: Overexpression and activation of the tyrosine kinase src in human pancreatic carcinoma. Biochem Biophys Res Commun 243: 503-508, 1998.

31. Thomas SM and Brugge JS: Cellular functions regulated by Src and family kinases. Annu Rev Cell Dev Biol 13: 513-609, 1997. 
32. Browaeys-Poly E, Cailliau K and Vilain JP: Signal transduction pathways triggered by fibroblast growth factor 1 addition. Role of Grb2, phosphatidylinositol 3-kinase, Src tyrosine kinase, and phospholipase C gamma. Eur J Biochem 267: 6256-6263, 2000.

33. Baxter RM, Secrist JP, Vaillancourt RR and Kazlauskas A: Full activation of platelet-derived growth factor beta-receptor kinase involves multiple events. J Biol Chem 273: 17050-17055, 1998.

34. Gelderloos JA, Rosenkranz S, Bazenet C, Kazlauska A: A role for Src signal relay by the platelet-derived growth factor alpha receptor. J Biol Chem 273: 5908-5915, 1998.

35. Blake RA, Garcia-Parami P, Parker PJ and Courtneidge SA: Src promotes PKC delta degradation. Cell Growth Differ 10: 231-241, 1999.

36. Erpel T, Alonso G, Roche S and Courtneidge SA: The Src SH3 domain is required for DNA synthesis induced by plateletderived growth factor and epidermal growth factor. J Biol Chem 271: 16807-16812, 1996.

37. Broome MA and Hunter T: Requirement for c-SRC catalytic activity and the $\mathrm{SH} 3$ domain in platelet-derived growth factor $\mathrm{BB}$ and epidermal growth factor mitogenic signaling. J Biol Chem 271: 16798-16806, 1996.

38. Rosenkranz S, DeMali KA, Gelderloos JA, Bazenet C and Kazlauskas A: Identification of the receptor-associated signaling enzymes that are required for platelet-derived growth factorAA-dependent chemotaxis and DNA synthesis. J Biol Chem 274: 28335-28343, 1999.

39. Twamley-Stein GM, Pepperkok R, Ansorge W and Courtneidge SA: The Src family tyrosine kinases are required for platelet-derived growth factor-mediated signal transduction in NIH 3 T3 cells. Proc Natl Acad Sci USA 90: 7696-7700, 1993.

40. Summy JM and Gallick GE: Src family kinases in tumor progression and metastasis. Cancer Metastasis Rev 22: 337-358, 2003.

41. Ito H, Gardner-Thorpe J, Zinner MJ, Ashley SW, Whang EE: Inhibition of tyrosine kinase Src suppresses pancreatic cancer invasiveness. Surgery 134: 221-226, 2003.

42. Summy JM, Trevino JG, Baker CH and Gallick GE: c-Src regulates constitutive and EGF-mediated VEGF expression in pancreatic tumor cells through activation of phosphatidyl inositol-3 kinase and p38 MAPK. Pancreas 3: 263-274, 2005.

43. Trevino JG, Summy JM, Gray MJ, Nilsson MB, Lesslie DP, Baker $\mathrm{CH}$ and Gallick GE: Expression and activity of Src regulate interleukin-8 expression in pancreatic adenocarcinoma cells: implications for angiogenesis. Cancer Res 65: 7214-7222, 2005.

44. Summy JM, Trevino JG, Lesslie DP, Baker CH, Shakespeare WC, Yang Y, Sundaramoorthi R, Metcalf CA, Sawyer TK and Gallick GE: AP23846, a novel and highly potent Src family kinase inhibitor, reduces VEGF and IL-8 expression in human solid tumor cells lines and abrogates downstream angiogenic processes. Mol Cancer Ther (in press).

45. Trevino JG, Summy JM, Lesslie DP, Parikh NU, Hong DS, Lee FY, Donato NJ, Abbruzzese JL, Baker CH and Gallick GE: Inhibition of Src expression and activity inhibits tumor progression and metastasis of human pancreatic adenocarcinoma cells in an orthotopic nude mouse model. Am J Pathol (in press).

46. Yezhelyev MV, Koehl G, Guba M, Brabletz T, Jauch K-W, Ryan A, Barge A, Green T, Fennell M and Bruns CJ: Inhibition of Src tyrosine kinase as treatment for human pancreatic cancer growing orthotopically in nude mice. Clin Cancer Res 10: 8028-8036, 2004.

47. He W, Myers MR, Hanney B, Spada AP, Bilder G, Galzcinski H, Amin D, Needle S, Page K, Jayyosi Z and Perrone MH: Potent quinoxaline-based inhibitors of PDGF receptor tyrosine kinase activity. Part 2: the synthesis and biological activities of RPR127963 an orally bioavailable inhibitor. Bio Med Chem Lett 13: 3097-3100, 2003

48. Bruns CJ, Harbison MT, Kuniyasu H, Eue I and Fidler IJ: In vivo selection and characterization of metastatic variants from human pancreatic adenocarcinoma by using orthotopic implantation in nude mice. Neoplasia 1: 50-62, 1999 .

49. Fan D, Poste G, O'Brien CA, Deid C, Ward NE, Earnest LE and Fidler IJ: Chemosensitization of murine fibrosarcoma cells to drugs affected by the multidrug resistance phenotype by the antidepressant trazodone: an experimental model for the reversal of intrinsic drug resistance. Int J Oncol 1: 735-742, 1992.
50. Yoneda J, Kuniyasu H, Crispens MA, Price JE, Bucana CD and Fidler IJ: Expression of angiogenesis-related genes and progression of human ovarian carcinomas in nude mice. J Natl Cancer Inst 90: 447-454, 1998

51. Radinsky R, Risin S, Fan D, Dong Z, Bielenberg D, Bucana CD and Fidler IJ: Level and function of epidermal growth factor receptor predict the metastatic potential of human colon carcinoma cells. Clin Cancer Res 1: 19-31, 1995.

52. Allgayer H, Wang H, Gallick GE, Crabtree A, Mazar A, Jones T, Kraker A and Boyd DD: Transcriptional induction of the urokinase receptor gene by a constitutively active Src. J Biol Chem 274: 18428-18437, 1999.

53. Waters CM, Connell MC, Pyne S and Pyne NJ: c-Src is involved in regulating signal transmission from PDGFß receptor-GPCR(s) complexes in mammalian cells. Cell Signal 17: 263-277, 2005.

54. Mori S, Ronnstrand L, Yokote K, Engstrom A, Courtneidge SA, Claesson-Welsh L and Heldin CH: Identification of two juxtamembrane autophosphorylation sites in the PDGF beta-receptor; involvement in the interaction with Src family tyrosine kinases. EMBO J 12: 2257-2264, 1993.

55. Kypta RM, Goldberg Y, Ulug ET and Courtneidge SA: Association between the PDGF receptor and members of the src family of tyrosine kinases. Cell 3: 481-492, 1990.

56. DeMali KA, Godwin SL, Soltoff SP and Kazlauskas A: Multiple roles for Src in a PDGF-stimulated cell. Exp Cell Res 253: 271-279, 1999.

57. Barone MV and Courtneidge SA: Myc but not Fos rescue of PDGF signaling block caused by kinase-inactive Src. Nature 378: 509-512, 1995 .

58. Coppola D: Molecular prognostic markers in pancreatic cancer. Cancer Control 7: 421-427, 2000.

59. Kotelevets L, van Hengel J, Bruyneel E, Mareel M, van Roy F and Chastre E: Implication of the MAGI-1b/PTEN signalosome in stabilization of adherens junctions and suppression of invasiveness. FASEB J 19: 115-117, 2005.

60. Goel R, Phillips-Mason PJ, Raben DM and Baldassare JJ: alphathrombin induces rapid and sustained Akt phosphorylation by beta-arrestin1-dependent and -independent mechanisms, and only the sustained Akt phosphorylation is essential for $\mathrm{G} 1$ phase progression. J Biol Chem 21: 18640-18648, 2002.

61. Baran CP, Tridandapani S, Helgason CD, Humphries RK, Krystal G and Marsh CB: The inositol 5'-phosphatase SHIP-1 and the Src kinase Lyn negatively regulate macrophage colony stimulating factor-induced Akt activity. J Biol Chem 40: 38628-38636, 2003

62. Aimakajornboon N, Szerlip NJ, Gozal E, Anonetapipat JH and Gozal D: In vivo PDGFß receptor activation in the dorsocaudal brain stem of the rat prevents hypoxia-induced apoptosis via activation of Akt and Bad. Brain Res 895: 111-119, 2001.

63. Langley RR, Fan D, Tsan RZ, Rebhun R, He J, Kim S-J and Fidler IJ: Activation of platelet-derived growth factor enhances survival of murine bone endothelial cells. Cancer Res 64: 3727-3730, 2004

64. Lokker NA, Sullivan CM, Hollenbach SJ, Israel MA and Giese NA: Platelet-derived growth factor (PDGF) autocrine signaling regulates survival and mitogenic pathways in glioblastoma cells: evidence that the novel PDGF-C and PDGF-D ligands may play a role in the development of brain tumors. Cancer Res 62: 3729-3735, 2002.

65. Shimamura H, Terada Y, Okado T, Tanaka H, Inoshita S, Sasaki S: The PI3-kinase-Akt pathway promotes mesengial cell survival and inhibits apoptosis in vitro via $\mathrm{NK}-\mathrm{kB}$ and Bad. J Am Soc Nephrol 14: 1427-1434, 2003.

66. Eberhard A, Kahlert S, Goede V, Hemmerlein B, Plate KH and Augustin HG: Heterogeneity of angiogenesis and blood vessel maturation in human tumors: implications for antiangiogenic tumor therapies. Cancer Res 60: 1388-1393, 2000.

67. Duxbury MS, Ito H, Zinner MJ, Ashley SW and Whang EE: Inhibition of Src tyrosine kinase impairs inherent and acquired gemcitabine resistance in human pancreatic adenocarcinoma cells. Clin Cancer Res 10: 2307-2318, 2004

68. Boyd DD, Wang H, Avila H, Parikh NU, Kessler H, Magdolen V and Gallick GE: Combination of a Src kinase inhibitor with a novel pharmacological antagonist of the urokinase receptor diminishes in vitro colon cancer invasiveness. Clin Cancer Res 10: $1545-1555,2004$. 